\title{
From a Separate Special Education to an Inclusive Education Paradigm in Estonia
}

\author{
Vadim Rõuk and Ene Mägi
}

\begin{abstract}
The objective of this article is to substantiate and outline attitudes for equality policies and practice for disabled students in Estonia from 1991-2004. It outlines the legislative context, positive steps that have been taken, and the gaps that remain in the country's laws. Upon gaining its independence from the Soviet Union in 1991, Estonia had to cope with multiple tasks to overcome economic and social instability. We examine the historical and contextual point of view of documents, legislative acts, and practical developments in educational inclusion based on the theoretical background of understanding disability. This article discusses also how Estonia's government pursued the international policy of protecting children's rights, especially the rights of disabled children, by developing necessary legislature to get education for special needs pupils and involving them in society as equal members. Our article demonstrates that the rights-based approach to education in Estonia is based on all human rights principles. The right to and opportunity for education and employment are confirmed. Student selection for curricula at different levels is carried out using pedagogical methods, not medical ones. The diagnosisbased designation/labelling of learners in daily communication has been abandoned. Movement between different curricula and forms of study has been enacted. Co-teaching of all children, teaching in an inclusive context, was set as a national task in Estonia in 2004: how to teach a broadly diverse student body, one that has not only pupils with special needs, but various talents, propensities, language barriers, etc. so that students in the classroom achieve good results equally.
\end{abstract}

Keywords: special needs, medical model, social model, integration, inclusion

\section{Introduction}

The inclusive education paradigm is based on the modern definition of disability by the World Health Organisation (WHO) and the American Association on Intellectual and Developmental Disabilities, which define disabilities in a functional and contextual way. ${ }^{1}$ The World Declaration on Education for All (adopted in Jomtien, Thailand in 1990) sets out a general vision: universalising access to education and promoting equity for all children. The major impetus for inclusive education was given at the World Conference

\footnotetext{
1 World Health Organisation, 'Disabilities.' Available: http://www.who.int/topics/disabilities/en/
} (accessed 18 May 2018). 
on Special Needs Education - Access and Quality - held in Salamanca, Spain in June $1994 .^{2}$

There are two main models that have influenced modern thinking about disability - the medical model and the social model. ${ }^{3}$ Historically, disability has been a segregating phenomenon and people with disabilities have been considered different. Disability has been conceptualised and measured differently in various countries.

The medical model of disability sees disability as a problem of the person, caused directly by disease, injury, or other health conditions that requires individualised treatment. In this case, the main issue is access to medical care. The main response on the political level is the revision or reform of health care policy. ${ }^{4}$ In the 1950s, a functional perspective of illness was developed based on Parsons' sociological paradigm, ${ }^{5}$ which states that the social world exists as a whole: social institutions and health care professionals have the right to check people's health and treat the patient until he or she is fully functional again.

The social perspective of disability developed in the 1960s and originated with a social-political movement that defines disability as a product of social and physical environment. This model emphasised that disability is not an individual issue or the person's personal problem: in order to improve their quality of life, it was necessary to change social attitudes, institutions, and policies. ${ }^{6}$

In recent decades, representatives of movements of people with disabilities and social and health researchers have emphasised the role of social and physical barriers; that is, a change from the medical model to the social model which sees disability as caused by society and not by changes within a person's body.

Besides problems of insufficient understanding of the implications of inclusive education in Estonia, many problems in implementation are caused by belief systems and practices that belong to a special education paradigm and continue to be used in inclusive education such as static assessment procedures

2 'World Conference on Special Needs Education: Access and Quality', in Salamanca Statement and Framework for Action on Special Needs Education, 1994. Available: http://www.right-to-education. org/sites/right-to-education.org/files/resource-attachments/Salamanca_Statement_1994.pdf (accessed 18 May 2018).

3 M. Ainscow, T. Booth, Index for Inclusion: Developing Learning and Participation in Schools, Bristol, Centre for Studies on Inclusive Education, 2002. Available: http://www.csie.org.uk/ resources/inclusion-index-explained.shtml (accessed 18 May 2018); M. Ainscow, D. A. Tweddle, Preventing classroom failure: and objectives approach, Chichester, John Wiley \& Sons, 1979.

4 'Ülevaade seadusandliku ja täidesaatva riigivõimu ning kohalike omavalitsuste õigustloovate aktide kooskõlast põhiseaduse ja seadustega' [An overview of the conformity of legislative and executive power's and local government's legislative acts with the Constitution and laws], Riigi Teataja [State Gazette], 2005. Available: https://www.riigiteataja.ee/akt/945214 (accessed 18 May 2018). The situation regarding the right of pupils with special needs to basic education is addressed in Part III 'Legal administrator - supervision activities.'

5 T. Parsons, The Social System, London, Routledge \& Kegan Paul, 1951.

6 M. Oliver, B. Sapey, Social Work with Disabled People, Basingstoke, Palgrave Macmillan, 2006. 
and labelling based on medical models of disability. The social model develops inclusive schooling, partnerships with communities, and parental involvement.

The concept of educational special needs and its development are complex as a whole and influenced by a variety of ideologies and movements. The use of the phrase "special educational needs" in a White Paper in Great Britain in 1980 boosted the demand to remove labeling in the context of the education system - grouping and classifying students - set an example for other European countries. The most important task should be identification of the specific educational needs of the child, but classifications based on the existing medical model do not make it possible to clearly identify the precise needs of the learner in the context of the education system. ${ }^{\text {? }}$

The purpose of this article is to substantiate and outline attitudes on equity policies and practices for disabled students in Estonia from 1991-2004. What were the political challenges and legislative steps introduced to support change in attitudes towards disabilities and inclusive education, and what were the ideals and what practical steps took place in inclusive education during the first decade of regaining independence?

We use historical analysis of legislative acts and other documents as well as research to understand and generalise the matter of changes.

\section{Challenges for policy-makers - attitudinal changes and policy development}

Reforming legislation to support inclusive education. The Education Act came into force on 30 March 1992, ${ }^{8}$ before the Constitution of the Republic of Estonia was adopted. ${ }^{9}$ The preconditions for this were created by perestroika in the late 1980s and the struggle to build a society based on democracy. Article 12 of the Constitution explicitly prohibited discrimination: "Everyone is equal before the law. No one can be discriminated against on the basis of nationality, race, colour, sex, language, origin, religion, political or other views, property or social status, or on other grounds." ${ }^{10}$ This paragraph did not specifically include disabilities but is covered by the term "other circumstances." Section 28 provided that people with disabilities were under the special care of state and local governments.

Estonia is a signatory of many international agreements on human rights, rights of persons with disabilities, and rights to education and employment. Estonia ratified the United Nations Convention on the Rights of the Child in 1991 as a reference document for future activities in protecting children's

\footnotetext{
${ }^{7}$ K. Wedell, 'Concepts of Special Educational Needs', Journal of Research in Special Educational Needs, vol. 3, no. 2, 2003, pp. 104-108.

8 'Republic of Estonia Education Act', Riigi Teataja [State Gazette], 1992. Available: https://www. riigiteataja.ee/en/eli/ee/Riigikogu/act/506012016003/consolide (accessed 18 May 2018).

9 'Constitution of the Republic of Estonia,' Riigi Teataja [State Gazette], 1992. Available: https:// www.riigiteataja.ee/en/eli/ee/rhvv/act/521052015001/consolide (accessed 18 May 2018).

${ }^{10}$ Ibid., Paragraph 12.
} 
education and health and the Salamanca Declaration in 1994, which affirms that "schools should accommodate all children - regardless of their physical, mental, social, emotional, linguistic or other conditions." 11 Estonia signed the UNESCO Declaration on Education for All in Dakar in 2000 and other related agreements. ${ }^{12}$

In light of international agreements, the use of terminology in the area of special needs was critically evaluated. The Education Act (1992) had abandoned Soviet-era definitions and terminology such as 'anomalous children', 'defective children', 'invalids', and 'handicapped' and replaced them with hälvik or hälviklapsed (child with deviations), which was only cautious distancing from the previous, in a linguistic sense. ${ }^{13}$ However, the meaning is degrading, rather disparaging, and poorly translated. Estonian society still needed time to abolish labelling and discriminatory terminology for human beings, as well as its use in everyday life through contracts and extended cooperation and agreements with national treaties.

In 2004, the term 'child/person with special needs' replaced 'child with deviation' in the 1992 Education Act, the 2010 Basic Schools and Upper Secondary Schools Act, and in all other acts and regulations. ${ }^{14}$ The term 'special educational needs' was not clearly defined in Estonian legislation until 2004. However, several factors ensured that the term 'special educational needs' was used for those learners: international co-operation, the need to be understood and to ensure that the school functioned as an educational institution, rather than as a medical institution.

Ideal and practical renewal processes. At the start of intense educational reforms (1987), Estonia had about 13000 children in special education, including 2200 in special groups in kindergartens. ${ }^{15}$ They were all categorised as 'defective' and 'anomalous' children on the basis of disabilities required for attending special schools and classes. Children with more severe intellectual and physical disabilities, who were recognised as incapacitated, were concentrated in social welfare institutions - a total of 450 children and young people in $1987 .{ }^{16}$

11 'World Conference on Special Needs Education: Access and Quality' in The Salamanca Statement and Framework for Action on Special Needs Education, 1994, p. 6. Available: https:// www.right-to-education.org/sites/right-to-education.org/files/resource-attachments/ Salamanca_Statement_1994.pdf (accessed 18 May 2018).

12 The Dakar Framework for Action: Education for All: Meeting our Collective Commitments, Dakar, World Education Forum, 2000. Available: https://unesdoc.unesco.org/ark:/48223/pf0000121147 (accessed 18 May 2018). Estonia also adopted the UN's 'Principles of Standard Rules for Equal Opportunities for People with Disabilities' on 16 May 1995.

13 'Republic of Estonia Education Act', Riigi Teataja [State Gazette], 1992. Available: https://www. riigiteataja.ee/en/eli/ee/Riigikogu/act/506012016003/consolide (accessed 18 May 2018).

14 Ibid.; 'Basic Schools and Upper Secondary Schools Act', Riigi Teataja [State Gazette], 2010, Article 93 (3). Available: https://www.riigiteataja.ee/en/eli/ee/Riigikogu/act/521062016007/ consolide (accessed 18 May 2018).

${ }^{15}$ E. Veskiväli, J. Kõrgesaar, Eripedagoogika Eestis. Eripedagoogika tänapäevaküsimusi [Special education in Estonia. Today's issues], Tartu, Tartu Ülikool, 1987, p. 15.

16 Ibid., p. 16. 
Estonia was the first in the Soviet Union to introduce special education classes in the 1970s in which special needs students were prepared to re-integrate into regular classes $^{17}$ and these were not completely eradicated. Traditional Soviet logopaedic classes were being replaced with remedial classes because similarities were observed in the background of these learning difficulties. The choice of the type of school was decided by medical-pedagogical committees and based primarily on the child's medical indicators. Special educators, specialists in 'defectology', and scholars were evaluated as teachers and specialists for special schools and classes. The philosophy and approach that supported special education as the best means to offset limitations associated with disability still drove the thinking and actions associated with disabled children at the end of 1980s and was criticised by leaders of education renewal. ${ }^{18}$

Perestroika opened the doors for various types of foreign assistance, further training, and exchanges of experience. It was foreign donors who noted the enormous social and educational segregation: separation of people with disabilities from community-based institutions, disability-differentiated school network, and labelling terminology mixed with medical categories in everyday practice. In a renewed situation, the debate about the need for equal treatment of people and the shortcomings of the current organisation of the state, including health and education, was intensified.

The beginning of the educational-innovative movement can be attributed to the Congress of Estonian SSR Teachers in March 1987. Following the Congress, working groups developed rapidly that initiated the conference of educators convened in 1988, which formulated the Estonian Educational Platform. ${ }^{19}$ In 1997, Educational Scenarios of Estonia ${ }^{20}$ were created. 'Learning society' became the keywords, and the desired educational strategy was named 'LearningEstonia': the goal was to create and actualise educational concepts that reflected the real needs and interests of society and its members. ${ }^{21}$

${ }^{17}$ F. Eisen, Tasandusklasside organiseerimisest ja tööst ópilaste ajutise mahajäävuse likvideerimiseks Eesti NSV-s [On organisation of levelling classes and work for liquidation temporary retardment of pupils in the ESSR], manuscript, 1972, Estonian Pedagogical Archives-Museum, K0045447-1, p. 23.

${ }^{18}$ P. Kreitzberg, 'Mis suunas liigub hälvikõpe?' [In which direction is the education of the disabled moving?], Edasi [Newspaper 'Edasi'], 26 March 1989.

${ }^{19}$ E. Kareda, et al. (eds.), Main Principles for Reorganization of the Public Education in Estonia, Tallinn, In-Service Teacher's Training Institute of Estonia, 1989.

${ }^{20}$ K. Loogma, R. Ruubel, V. Ruus, E-S. Sarv, R. Vilu (eds.), 'Estonia’s Education Scenarios 2015. The $21^{\text {st }}$ Century Learning Initiative.' Available: http://www.21learn.org/activities/events/ estonias-education-scenarios-2015/ (accessed 27 June 2017).

21 'Eesti Haridusfoorumi tegevusest 1995-2015. Vaade tulevikku' [Activities of the Estonian Education Forum 1995- 2015. View to the Future], in Eesti Haridusfoorum [Estonian Education Forum], 2015. Available: https://www.haridusfoorum.ee/14-meist/97-eesti-haridusfoorumitegevusest-1995-2015-vaade-tulevikku (accessed 27 June 2017). 


\section{Estonian schools and the road to inclusive education}

The gradual introduction and correction of legislation in the field of education showed the goodwill of the state to increase coherence, tolerance, and sustainability at both the individual and national levels. Each society needed to consider the traditions and beliefs of its past in terms of how people with disabilities were named and placed in society to make corrections for the future.

Until regaining independence, a segregated education system was implemented as the only option for children with special needs. In independent Estonia, this was seen as a discriminatory, marginalizing, and a decaying organization that was not suited to the new values and the concept of human rights.

Gradually, the term 'integration' replaced 'segregation', which characterises the process of inclusion children with special needs during the period under review. Having recognised the history of segregation, integration was formulated as a programmatic principle in new social practice and institutional reforms in Western societies in the 1960 s. $^{22}$ The reforms had three core principles:

1) The right to schooling and education for disabled children. There were groups of children who didn't have this right due to their disabilities;

2) The right to education in local schools for disabled children was originally formulated as an attack on centralised institutions established as special schools for designated categories (e.g., the separate special school system); and

3) Total reorganization of the special education system, focusing on all aspects from the identification of its clients to financial issues and finally followed by integration. ${ }^{23}$

By 2004, the right to education for all children with special needs was guaranteed by law. School organisation included children with learning difficulties and children with disabilities to be integrated into mainstream schools in 1999-2000. Meanwhile, segregating elements were noted in the content, form, and name of the assistance provided. For example, children with learning difficulties could be provided with assistance in the "leveling" class or correctional group. In schools, including special schools, the scope and organization of support varied, but the needs of the learners were similar. Moreover, naming the type of assistance sooner labelled rather than supported the children. ${ }^{24}$

${ }^{22}$ L. Vislie, 'From Integration to Inclusive: Focusing on Global Trends and Changes in Western European Societies,' European Journal of Special Needs Education, vol. 18, no. 1, 2003, p. 18.

23 Ibid., p. 20.

24 'Ülevaade seadusandliku ja täidesaatva riigivõimu ning kohalike omavalitsuste õigustloovate aktide kooskõlast põhiseaduse ja seadustega. Õiguskantsler, peatükk III, 2005' [An overview of the conformity of legislative and executive power's and local government's legislative acts with the Constitution and laws, Chancellor of Justice, chapter 3, 2005], Riigi Teataja [State Gazette]. Available: https://www.riigiteataja.ee/akt/945214 (accessed 18 May 2018). 
The Estonian Vocational Educational Institutions Act contained separate provisions aimed at enabling people with disabilities to study vocational education. ${ }^{25}$ It led to an increase in the number of special needs students in vocational education: by 1998-1999, there were ten special classes for special needs students in vocational education institutions with a total of 197 students, most of whom had intellectual disabilities. ${ }^{26}$

During these years, the number of special needs children increased in regular schools, professional counselling improved, and tolerance towards people with special needs developed. A change in attitude and national measures, such as the doubling of the upper limit for general expenses for special needs pupils in vocational education and training in comparison to those in the "ordinary" classroom, resulted in more special needs students enrolled in vocational training: in 2002-2003, there were almost 300 students with special needs in 22 of 81 vocational schools. ${ }^{27}$

Laws governing the education of children with special needs allow identification of two classifications. The first was physical special educational needs arising from health, the content/diagnosis of which required teaching either at a different level in the curriculum ${ }^{28}$ or study at a special school and special needs support applied - speech therapy, studying in a remedial class, or receiving remedial lessons. The second defined special educational needs arising from adaptation and behavioural difficulties, including individualised curriculum, psychological counselling, levelling classes and correctional training, and special schools. Special education could be provided in special classes in regular schools - remedial classes for children with learning difficulties, support classes for children with mild intellectual delays, subsistence classes for children with moderate under-development, and care classes for children with severe intellectual development delays. ${ }^{29}$

25 'Vocational Educational Institutions Act', 2013, Riigi Teataja [State Gazette]. Available: https:// www.riigiteataja.ee/en/eli/504022014002/consolide (accessed 18 May 2018).

${ }^{26}$ Rights of People with Intellectual Disabilities: Access to Education and Employment in Estonia: Monitoring Report, New York, Open Society Institute, 2005, pp. 66-67. Available: https://www. opensocietyfoundations.org/sites/default/files/estonia_2005_0.pdf (accessed 18 May 2018).

${ }^{27}$ Leelo Ainsoo (Astangu Vocational Rehabilitation Centre employee and former department leader), interview by Ene Mägi, 2004, Personal archives of Ene Mägi.

28 'Approval of a Simplified Curriculum for Basic Schools. Minister of Education Regulation No. 21 of 24.03.1999, Riigi Teataja [State Gazette]. Available: https://www.riigiteataja.ee/ akt/12743986 (accessed 28 March 2016).

29 'Basic Schools and Upper Secondary Schools Act', Riigi Teataja [State Gazette], 01.09.2010. Available: https://www.riigiteataja.ee/en/eli/ee/Riigikogu/act/521062016007/consolide (accessed 10 October 2018); 'Põhikooli lihtsustatud riikliku õppekava (abiõppe õppekava) kinnitamine' [Approval of simplified basic school curriculum], Riigi Teataja [State Gazette], 24.03.1999. Available: https://www.riigiteataja.ee/akt/792367 (accessed 28 October 2018). Next versions of 2002, 2004 etc. were the most complete acts became into force in 2010. See 'Põhikooli lihtsustatud riiklik õppekava' [Simplified basic school curriculum], Riigi Teataja [State Gazette], 28.12.2010. Available: https://www.riigiteataja.ee/akt/128122010014 (accessed 28 October 2018). The possibility of individualised curriculum was present in all projects and versions of National Curriculum since 1989. 
The feature of inclusive education in this arrangement was a common learning environment, socialisation with peers in the neighbourhood, sharing school resources, and family proximity. The Learning-Estonia strategy paper included the sub-theme 'The teacher is the key', which highlighted the key role of the teacher in changing the education system. ${ }^{30}$ Updated teacher training curricula included specifics of teaching children with special needs on the basis of the nature of the disability. Specialists were being prepared at Tallinn University and the University of Tartu. ${ }^{31}$

The national 'coping' curriculum was adopted at the end of 1999 by the Ministry of Education ${ }^{32}$ and renewed in 2002. A coping curriculum - a simplified version of the regular curriculum - was needed because of maximum educational obligations for learners with various abilities and needs. The preconditions for differentiation of curricula evolved due to changes in attitudes in society that supported these changes. Special needs people explained their needs and opportunities to the public: national social policies, parents' associations, and external training had created the basis to look at people with special needs, including children, as full-fledged members of society.

The National Curriculum for children with moderate intellectual disabilities was designed similarly for every grade as for the regular curriculum. Curriculum objectives emphasised preparation of children for an independent life (as much as possible), development of personal talents, and sustainability of education..$^{33}$ The legal necessity to differentiate teaching according to the needs of the learners led to more careful studies of children, involvement of parents, and a more tolerant society in order to facilitate the learner's actual needs. As a result, a new trend emerged - the number of children with special educational needs in regular schools increased.

The number of pupils with special needs in schools of general education increased year by year: by $2006,84,6 \%$ of special needs pupils studied in general education schools. ${ }^{34}$ The number of students with special needs increased most in "ordinary" classes in regular schools, indicating acceptance of inclusive education by schools and the general public. The number of home-schooled children or absent from education is unavailable as data transmission and storage by the Estonian Education Information System only began in 2004: the exact number of children with special needs prior to 2004 is not known, so

30 Õpi-Eesti 2001 [Learning Estonia 2001], Tallinn, Ministry of Education, 2001, p. 10.

${ }^{31}$ K. Kukk, Erivajadused hariduses, kokkuvõte [Special needs in education, summary], Tallinn, Haridus - ja Teadusministeerium, 2004. p. 10.

32 'Toimetuleku riiklik õppekava' [National Coping Curriculum], Riigi Teataja [State Gazette], 15.12.1999. Available: https://www.riigiteataja.ee/akt/81091 (accessed 28 June 2018).

33 'Põhikooli lihtsustatud riiklik õppekava' [Simplified Basic School Curriculum], Riigi Teataja [State Gazette], 16.12.2010. Available: https://www.riigiteataja.ee/akt/128122010014 (accessed 28 October 2018).

${ }^{34} \mathrm{H}$. Kanep, Analü̈̈ haridusliku erivajadusega öpilastest ja tugiteenuste kättesaadavusest ópilastele. Lópparuanne. [Analysis of pupils with special educational needs and availability of support services for students. Final report], Haridus- ja Teadusministeerium, 2008, p. 16. Available: http://dspace.ut.ee/bitstream/handle/10062/40911/Uld_HEV.pdf (accessed 25 May 2018). 
no comparable data exists. Moving towards inclusive education more attention was paid to terminology used at the educational area. The medical terms that were largely used before general ones replaced them were sometimes too general to cover the specific needs of learners. For example, the term 'multiple disability' does not indicate the specifics of the student's special needs, and the term 'learning difficulties' requires a more precise definition for the purpose of implementing measures.

It followed that learning opportunities for children with special needs should have provided similar opportunities as for regular students, but this objective was not achieved. Statistics from 2002-2005 show that of the children who graduated from special needs schools or classes, $68 \%$ moved on to vocational education. ${ }^{35}$ There were no specific goals for schools and classes for special needs children in the Basic Schools and Upper Secondary Schools Act. The Act stated that special classes could be formed in state and municipal schools, if necessary and depending on the needs of students, in primary and secondary schools or sanatorium schools. ${ }^{36}$

We can conclude that learning in regular schools created better opportunities for disabled students to further their education and access the labour market. The Basic Schools and Upper Secondary Schools Act of 2003 established counselling committees for special needs education in the education system. ${ }^{37}$

On the road to an inclusive society, several approaches were taken in Estonia: 1) Expert disability diagnosis provided a better understanding of the organization of assistance and learning and creation of initiative based on personal needs; 2) Talented children also benefited from the adaptation of curricula to each child's individual needs; 3 ) The new approach did not try to make a disabled person "normal" but accepted her/him as one of us; and 4) Increased tolerance reduced the gap between the medical and social model and the social model merged into a rights-based model ${ }^{38}$ focusing on inclusion in society.

It should be noted that the Soviet-era disability-centred, or medical approach, to organising education for children with more severe disabilities was not completely forgotten. Attempts were made to correspond three levels of intellectual development delay to corresponding curricula - simplified (mild delay), coping (moderate delay), and curriculum of care (severe delay). The diagnosis determined the curriculum, and either a special school

35 'Erivajadustega laste õppimisvõimalused' [Study opportunities for children with special needs], in Riigikontroll. Kontrolliaruanne nr OSIII-2-6/06/93, 10.11.2006 [National Audit Office. Control Report No. OSIII-2-6 /06/93, 10.11.2006], Tallinn, 2006, p. 28. Available: https://www.digar.ee/ arhiiv/et/raamatud/11866 (accessed 24 June 2016).

36 'Basic Schools and Upper Secondary Schools Act, Paragraph 93 (3),' Riigi Teataja [State Gazette], 2003. Available: https://www.riigiteataja.ee/en/eli/ee/Riigikogu/act/521062016007/consolide (accessed 28 October 2018).

${ }^{37}$ Ibid.

${ }^{38}$ U. Miller, S. Ziegler, 'Handicap International Christoffel-Blindenmission', in Manual Making PRSP Inclusive, 2006. Available: http://documents.worldbank.org/curated/en/591511520425305241/ pdf/123975-WP-ENGLISH-Making-PRSP-inclusive-PUBLIC.pdf (accessed 21 June 2018). 
or a special class in a regular school was suggested. By law, every child had the right to attend school near home, but until 2004, this was only a theoretical opportunity. The legislation did not specify precisely what schools need to change in their learning environments to meet the specific needs of children, so the situation remained uncertain. ${ }^{39}$

\section{Conclusion}

By the time Estonia joined the European Union in 2004, the state had created legislation in many fields, adopted main international agreements, and attempted to democratise society. The process of democratisation of education was progressive, especially as regards students with special needs. Implementation of inclusive education needed simultaneous abandonment of the former medical or disability-oriented approach and acceptance of completely new ideas, terminology, and attitudes to give all children equal footing in an all-inclusive education.

In Estonia, a historically literate state, significant pressure on the performance of education has always existed, and the categorisation/classification of learners was a form of an individualised approach rather than a deliberate desire to segregate and marginalise. During the transitional period from 1991 to 2004, most Soviet classifiers based on mental activity survived as the basis for the differentiation of learners in corresponding educational institutions and curricula.

Compared to other European countries, the proportion of students with special educational needs was rather high, $15 \%$ of all students in 2006. ${ }^{40}$ Nonetheless, the rights-based approach to education in Estonia was based on all human rights principles. Laws guaranteed equal treatment of all children, obligation and availability of education, and the right and opportunity for continuing education and employment. Differentiation at different levels was carried out using pedagogical methods, not medical ones, and movement between various curricula and forms of study was enabled. Diagnosis-based labelling of learners has been completely abandoned in daily conversation. Practical expression of inclusive education abandoned labelling in the educational field.

Teaching in an inclusive context was set in 2004 as a national task in Estonia: how to teach a broadly diverse student body, one that has special needs, various talents, language barriers, and other issues, to achieve good results.

\footnotetext{
${ }^{39}$ E. Tiitus, 'Erivajadusega õpilane tavakoolis ja suhtumine erivajadusega laste tavakooli kaasamisse' [Special needs students in regular schools and attitudes toward inclusion of special needs children into regular schools], Thesis, Tallinn Pedagogical University, 2000, p. 16.

${ }^{40} \mathrm{H}$. Kanep, Analü̈̈ haridusliku erivajadusega õpilastest ja tugiteenuste kättesaadavusest ópilastele. Lópparuanne [Analysis of pupils with special educational needs and availability of support services for students. Final report], Haridus- ja Teadusministeerium, 2008, p. 5. Available: http://dspace.ut.ee/bitstream/handle/10062/40911/Uld_HEV.pdf (accessed 25 May 2018).
} 